\title{
Consortia initiatives in cataloguing, bibliographic and indexing services in Nigeria
}

\author{
Charles O. Omekwu \\ Nigerian Institute of Advanced Legal Studies, P.M.B 12820, Lagos, Nigeria \\ omekwucharles@gmail.com \\ Anyaogu Uluocha \\ Nigerian Institute of Advanced Legal Studies, P.M.B 12820, Lagos, Nigeria \\ uluanyaogu@yahoo.com
}

\begin{abstract}
The paper examines the factors which are critical to the emergence of consortia efforts in cataloguing, bibliographic and indexing services. It focuses on the management and methodological issues essential to the evolution of a functional consortium in Nigeria. A methodological framework for a functioning consortium is proposed. Key factors discussed include management and operational framework, administration and managing resources. Others are funding and infrastructure. The paper highlights the emergence of consortia in Nigeria partly because of the rising costs and complexities of information resources, and decreasing budgets, while at the same time providing the user community with optimal access to needed information. The mission of consortia, consortia efforts in cataloguing, bibliography and indexing as well as Union, Virtual and Shared system catalogues are examined as the possible products of the consorting partners. The paper recommends that the cataloguer is a critical variable in the computational equation designed to evolve consortia in cataloguing, bibliography and indexing services. The challenge however, is to leverage ICT in the evolutionary process.
\end{abstract}

\section{Introduction}

Libraries not only collect and preserve materials; they also provide access to information resources. The intellectual basis for providing such access is the organization and cataloguing of materials for their clientele. Libraries are one of the major supporting agencies involved in the process of information production, processing and provision. Consequently, both the information systems and the information professionals are adapting to meet the changing needs and growing expectations of the users (Jalloh, 2000). The initiatives and development in the areas of automation, networking, resources sharing, consortia, digital libraries, and electronic document delivery have led to the emergence of new practices in the operational and management approaches of libraries 
the world over. Hence, as library resources migrate from print-based materials to digital resources, one enduring role of libraries will be their intellectual task of cataloguing, that is, imposing order on diverse resources with the goal of making those resources easier to discover, manage, and more searchable with remotely accessible Online Public Access Catalog (OPAC) systems. At the same time, due to reduced budgets and rising costs, libraries have formed consortia to share resources, collections and services.

The evolution of consortia initiatives needs to be situated within the technological, technical, and financial contexts relating to the optimization of information resources, sources and services. Information resources for instance are becoming complex and multi-formatted. Paper-based resources such as books, reference materials, journals, conference proceedings, newsletters, newspapers, government and non-governmental publications are being produced daily by multiple individuals and institutions in the knowledge and commercial sectors. Information explosion is no longer a new terminology in the vocabulary of the information professional and practitioner. But the novelty of the situation is the emergence of the virtual environment. Information technology tools and systems have created a new world or class of information resources based on electronic, digital and virtual systems. A hybridization of the traditional paperbased systems and virtually domesticated resources is already a compelling experience of library and information management institutions.

It is imperative to indicate that in the evolving information resource pool, no single library can afford to capture and contain all the valuable information available in the world-wide resource pool. Consortia have therefore emerged partly as a result of rising costs of library materials, the complexities of information resources and decreasing budgets, while at the same time providing the user community with optimal access to needed information.

\section{Conceptualizing consortia}

Kanter (1990) has described consortia as multi-organizational service alliances where a group of organizations with a similar need, often in the same industry, band together to 
create a new entity to satisfy their collective need. It is a group formed for an enterprise beyond the resources of any of its members and provides benefits to all of them.

Smilor and Gibson (1991) describe a consortium as often being composed of companies (that is shareholders) that seek mutually beneficial co-operative research while remaining competitors in the marketplace. Kammourie - Charara (2005) is of the view that a consortium is a "formal association of a number of organizations, usually in a specific geographical area, with agreed goals and objectives. Services covered can include collection development, cataloguing, computer alliances, systems support, education and training, inter-library loans, library automation, purchasing, etc”. Lee and Lee (1992) seem to be more practical in their definition of a consortium by including research organizations other than private firms. For them, a consortium connotes a co-operative research effort among companies, universities, industries, and/or government typically aimed at helping the participants maintain their leadership position or gain an edge over their international competitors in a particular industry.

Consortia are common in the non-profit sector, for example, libraries. The factors driving the growth of consortia among libraries are globalization of the library resources, technological trends and the information explosion experienced by libraries over the last two decades.

The missions for forming library consortia are as follows:

* To cope with changes that are taking place in libraries;

* To keep pace with user's requests and expectations in libraries, in particular in the e-resources field;

* To co-operate between libraries in the best interests of library users in the most economical way;

* To build a network of library clientele;

* To improve and expand library services and resources; 
* To give priority to the acquisition of library resources in digital format and to make every effort to provide users with efficient and the most cost-effective access to such resources;

* To build a network of libraries

* To improve the working relationship among librarians and provide an opportunity for them to learn from each other;

* To build liaisons with other regional and international libraries;

* To eliminate duplicated efforts in original cataloguing;

* To facilitate the sharing of library resources through inter-library loan services;

* To achieve standardization in cataloguing, indexing and abstracting services as well as bibliographic services in libraries;

* To increase opportunities for professional librarians;

* To facilitate transfer of services among member libraries;

* To provide a buffer for members against professional threats; and

* To obtain immediate access to library resources.

\section{Consortia efforts in Cataloguing}

Advances in information technology have affected all aspects of library services and cataloguing is no exception. Automation in the form of time-saving devices, such as bibliographic utilities, and sophisticated editing capabilities in integrated library systems, means that cataloguing is light years from the days of filling in cards written meticulously in 'library hand'. Library consortia will allow for greater standardization of data, multiple and remote access to information resources and easy sharing, because; the pattern of shared cataloguing by the consortia will benefit the users. There are several efforts to operate library consortia at regional, national or international levels. The Washington Research Library Consortium (WRIC, 2004) is a good regional resource-sharing organization established by several universities in the Washington, D. C. metropolitan area to expand and enhance the information resources available to their students and faculty. The International Coalition of Library Consortia (ICOLC, 2004) is an informal organization that began in 1997. Comprising about sixty library consortia in the United States, Canada, the United Kingdom, the Netherlands, Germany, Israel and Australia, the 
coalition represents over 5,000 member libraries worldwide. The coalition serves primarily higher education institutions by facilitating discussion among its members on issues of common interest (Francis, 2006).

More and more libraries are joining together in consortia so that they can share each other's collections. Today, libraries tend to borrow from each other more so that they need to buy less. However, be it through a formal consortium or an informal arrangement, a group of libraries can work together to find ways to operate collectively and gain new efficiencies. An online catalogue that can simultaneously search the collections of a group of libraries is an essential component of a resource-sharing cooperative. Through the implementation of such a combined catalogue and other resourcesharing arrangements, a library can expand the amount of materials available to its users. The catalogue of participating consortia libraries will include the following:
* Union catalogue
* Virtual catalogue
* Shared system union catalogue

A union catalogue is a physical union of multiple, individual library catalogues. It is a result of group efforts on cataloguing by a number of libraries. It provides users with the ability to consistently search for records from multiple libraries in the sense that these records are indexed consistently. The goals of a union catalogue are to:

$>$ Catalogue most cost effectively;

> Increase the supply of quality records, both bibliographic and authority ones;

$>$ Develop and maintain mutually acceptable standards;

$>$ Increase access and sharing of bibliographic and authority databases of the participating libraries;

$>$ Develop of an inter-library loan system with real access to materials and document delivery ;

$>$ Link document suppliers and electronic journals;

$>$ Use shared resources; and

$>$ Produce National Bibliography in electronic format. 
In fact, a union catalogue is a shared bibliographic database of all collections in the participating libraries and their locations. It is an essential component of a resourcesharing co-operative because it allows users to search simultaneously the collections of a group of libraries in the consortia.

Participating libraries in the consortia with physically separate catalogues can create a combined catalogue 'virtually' through a layer of additional software. It is a relatively simple, low-cost way to establish a multi-library catalogue, and does not disrupt the existing environment. A virtual catalogue can be implemented for a group of libraries that use different brands of library automation systems. The library's own web-based online catalogue is the primary interface for searching for materials, but offers an alternative that library users can use to find materials not held by their own library. It serves as a tool for increasing the level of resource sharing among a group of libraries.

A virtual catalogue has a variety of features which include a display of titles held by each library, information about multiple copies and holdings and display of the circulation status of items retrieved in a search. Moreover so, a virtual catalogue interface should also include linkages to an inter-library loan system, allowing users easy options for requesting materials. Creating virtual catalogues, for the most part, is an approach that works and has been successfully implemented by a number of library consortia.

A shared-system union catalogue is a multi-library catalogue for all the libraries in a consortium. All the participating libraries are expected to make use of a single library automation system. Thus, since each of the records resides in the same database, providing the capacity to search across all the library's collections is easily accomplished. This model of searching is more straightforward, avoiding the complex matrix of connections involved in the virtual catalogue model. The shared system approach for establishing a union catalogue generally offers higher reliability and faster performance. 


\section{Consortia efforts in bibliography}

Library bibliographic services are a core element of the research endeavor. They provide tools in the form of catalogues, indexes and abstracts, as well as web pages that link library users to the materials they want. Also bibliographic services provide concise cataloguing, accurate authority control, and timely processing of materials to give library users up-to-date access to the collections.

Library bibliographic services grew up at various points in time, each with a different purpose, and they do not interoperate effectively (Riemer, 2006). Libraries offer local catalogues, union catalogues, e-resource management systems, abstracting and indexing databases, institutional repositories, and local digital library collections. Federated searching needs to pull data from all these separate services and combine resources in new and valuable ways for users. Hence, libraries tend to form a consortium so as to offer better bibliographic services using seamlessness, simplicity and common language searching.

\section{Proposed methodological framework for Nigeria's Consortia Initiatives}

Lowe and Freighan (2006) describe consortium models in database delivery with particular focus on the Australian experience. Issues that require decisions are highlighted as follows:

(i) Will the final decision affect local information access policies?

(ii) How will it affect collection development at a local level?

(iii) Does the decision have financial implications which will affect the library's ability to buy or continue to buy other products which patrons want?

(iv) Can the library continue to maintain a balance in the collection or equity of access for patrons?

(v) Who bears the hidden costs such as training, hardware and software requirements?

(vi) How does the consortium effort handle immediate, short-term, mid-term and long-term funding and technical support? 
(vii) Who has the ultimate decision-making powers in resolving difficulties and disagreements that may arise?

(viii) Who has the responsibility for the management of the consortium and the critical decision-making process?

(ix) Will the structure of the consortium be formal or informal?

The vital steps in relation to project management orientation leading to the evolution of a consortium are indicated in table 1 below.

Table 1: Project management orientation leading to the evolution of a consortium

\section{Critical skills required}

Planning

Leadership

Leadership / Planning organization

Planning

Leadership / Planning organisation /Control

Planning/ Organisation

\section{Generic project definition process}

$1 \quad$ Establish broad goals and objectives.

$\sqrt{n}$

2 Make a project announcement to potential stakeholders.

ת

$3 \quad$ Agree and establish consortium membership, roles and responsibilities and decision-making process.

ת

$4 \quad$ Categorize needs and review and define needs.

$\sqrt{3}$

\begin{tabular}{|c|c|c|c|}
\hline$\Leftrightarrow$ & \multicolumn{3}{|c|}{$\begin{array}{l}\text { Scope these needs according to the following to formally define actual } \\
\text { goals and objectives. }\end{array}$} \\
\hline 仓 & \multicolumn{2}{|l|}{$\sqrt{3}$} & $\sqrt{3}$ \\
\hline 仓े & $\begin{array}{l}\text { Develop options including } \\
\text { alternatives. }\end{array}$ & \multirow[t]{2}{*}{$\Leftrightarrow$} & $\begin{array}{l}\text { Define boundaries and } \\
\text { responsibilities. }\end{array}$ \\
\hline 仓 & 企 & & 企 \\
\hline \multirow[t]{2}{*}{ 的 } & Estimate cost and time required. & $\Leftrightarrow$ & Identify and assess risks. \\
\hline & $\sqrt{3}$ & & $\sqrt{ }$ \\
\hline 6 & \multicolumn{3}{|c|}{$\begin{array}{l}\text { Generate Statement of Work (SOW) including agreed to and scoped goals } \\
\text { and objectives }\end{array}$} \\
\hline
\end{tabular}




\begin{tabular}{|c|c|c|c|}
\hline & & $\begin{array}{l}7 \\
8 \\
9\end{array}$ & $\begin{array}{l}\text { Document decision-making methodology } \\
\text { Document schedule include time frames } \\
\text { Document measurement criteria. }\end{array}$ \\
\hline & $\hat{\imath}$ & & $\sqrt{3}$ \\
\hline \multirow[t]{2}{*}{ Control } & 绝 & 10 & $\begin{array}{l}\text { Get feedback from consortium members on SOW, decision making } \\
\text { methodology, schedule, and measurement criteria. }\end{array}$ \\
\hline & $\hat{\imath}$ & & $\sqrt{ }$ \\
\hline \multirow[t]{2}{*}{ Organisation/Control } & $\hat{\imath}$ & 11 & $\begin{array}{l}\text { Adjust design and scope as appropriate. Document and sign off. Distribute } \\
\text { document to all consortium members. }\end{array}$ \\
\hline & 仓 & & $\sqrt{ }$ \\
\hline \multirow[t]{2}{*}{$\begin{array}{l}\text { Organisation/ } \\
\text { Planning }\end{array}$} & B & 12 & $\begin{array}{l}\text { Call for trials including SOW, decision-making methodology, schedule, and } \\
\text { measurement criteria. }\end{array}$ \\
\hline & 仓 & & $\sqrt{ }$ \\
\hline \multirow[t]{2}{*}{ Organisation/Control } & 它 & 13 & $\begin{array}{l}\text { Review trial process according to SOW, decision-making methodology, } \\
\text { schedule, and measurement criteria. }\end{array}$ \\
\hline & 仓 & & $\sqrt{ }$ \\
\hline \multirow[t]{2}{*}{ Control } & 估 & 14 & $\begin{array}{l}\text { Make recommendation based on SOW, decision-making methodology, } \\
\text { schedule, and measurement criteria. }\end{array}$ \\
\hline & $\hat{\imath}$ & & $\sqrt{3}$ \\
\hline \multirow[t]{2}{*}{$\begin{array}{l}\text { Leadership/ } \\
\text { Organisation /Control }\end{array}$} & $\hat{\imath}$ & 15 & Get feedback from consortium members on decision. \\
\hline & $\hat{\imath}$ & & $\sqrt{3}$ \\
\hline \multirow[t]{2}{*}{$\begin{array}{l}\text { Leadership/ } \\
\text { Organisation }\end{array}$} & es & 16 & $\begin{array}{l}\text { Adjust decision if necessary based on SOW, decision-making methodology, } \\
\text { schedule, measurement criteria and consortium feedback. }\end{array}$ \\
\hline & & & ת \\
\hline $\begin{array}{l}\text { Relax, you have made } \\
\text { it this far! }\end{array}$ & & 17 & $\begin{array}{l}\text { Document sign off and formally notify consortium members and vendors of } \\
\text { decision. }\end{array}$ \\
\hline \multicolumn{4}{|c|}{ Adapted from Deidre Lowe \& David Feighan: Saving a buck and avoiding the muck: } \\
\hline
\end{tabular}




\section{Proposed management framework for consortia initiatives in Nigeria}

Omekwu (2003a, b) has conceptualized frameworks for agricultural and legal networks in Nigeria. Issues raised in those conceptualizations are critical in the consideration of the features for Consortia efforts in cataloguing, bibliography and indexing. First, a clear definition of the status and mandate of a consortium provides the modus operandi for a sustainable library Consortium. Its scope of operation, activities, objectives and products must be clearly delineated.

Second, composition and obligation which deals with system globality, that is all the aspects of the consortia component separates the main consortia into various elements that will make up the consortia. It should include all stakeholders at national and sectoral levels. Certainly, cataloguing and classification professionals in all categories of libraries are critical variables.

Third are issues of administration and coordination. Every consortium requires appropriate coordination of consortia activities and relationships. The Cataloguing, classification and indexing section of the Nigerian Library Association is most technically situated to coordinate consortia efforts in cataloguing, bibliography and indexing. It is only logical that the Chief Executive Officer of the Consortia efforts should reside with whoever chairs that section.

Fourth, is the need for the analysis and systemization of the information needs of consortia partners. It must be emphasized that acquisition of information resources is not enough. Acquired resources must be both need-specific and satisfying. Partners' participation will be enhanced or endangered depending on whether or not their institutions benefit from the consortia arrangement.

Fifth, an information resource management system has to be designed. Internally generated and other externally acquired information must be seen as vital resources that must be organized, maintained and made available to actual and potential consortia beneficiaries. 
Sixth, participation in consortia may be open to all interested institutions. But standards are essential to ensure uniformity in data collection, organization and retrieval processes. Data input formats need to be designed and standardized for use by consorting partners.

Seventh, initial investment in computer-based consortium infrastructure could be expensive. Consortia coordinating institution and the components would need financial empowerment to procure the basic facilities and installed.

Eighth, an appropriate computer and telecommunication system is essential to keep upto-date advances in computer-based networks. To achieve effective communication among partners, the appropriate transmission control/Internet protocol, and compatible hardware and software need to be put in place. Perhaps it is important to state here that no consortium is more effective than the professionals behind the IT. The complete metamorphosis of an effective library consortium is critically dependent on the quality and commitment of the information professionals who are involved in the operation of the information apparatus of the partnering institutions.

\section{Conclusion}

Consortia efforts in cataloguing, bibliography and indexing are critical to optimal exploitation of the resources occasioned by decades of unprecedented information explosion. That explosion indicates that no single library can procure, process and provide all the information that is pertinent to individual progress and institutional productivity. Budget constraints and burgeoning costs beckon librarians to pool their resources together to provide the clientele with diverse information resources and services. Bridge-building consortia initiatives will enable individuals to find information in institutions it is available. Such consortia efforts are vital for information resource systemization, and service standardization. Systemization and standardization are peculiar professional practice of the cataloguer, bibliographer and indexer. The cataloguer is therefore a critical variable in the computational equation designed to evolve consortia for cataloguing, 
bibliography and indexing. The challenge is to leverage ICT in the evolutionary process.

\section{Recommendations}

The following recommendations are made:

One, a tactical unit within the cataloguing, classification and indexing section of the Nigerian Library Association should be set up to develop the organizational framework, operational modalities and institutional obligations. It should study consortia efforts in these critical areas in other nations and institutions and come up with a practical and implementable agenda for the country.

Two, the National Library of Nigeria (NLN) should continue with The Union Catalogue project and should partner international bibliographic institutions like the OCLT, Library of Congress and the International Coalition of Library Consortia in the area of human resources development, infrastructural needs, ICT applications and national consortia conceptualization, implementation and coordination. Lessons from the experience(s) of such successful consortia efforts may be all that is needed to move the national efforts forward.

Third, sectoral Consortia Initiatives should be reinvigorated. The Nigerian Institute of Advanced Studies could coordinate the legal bibliography and indexing consortia initiatives by partnering University Law Faculties, the Nigerian Law School, the Supreme Court of Nigeria, the National Judicial Institute and all other libraries that belong to the Nigerian Association of Law Libraries. Such sectoral or subject-based consortia effort should then be integrated into the national initiatives.

Fourth, the nation's Library and Information Science Schools should research into the technical, organizational, and operational issues and digital applications for consortia efforts. 
Finally, all library consortia members should apply digital and virtual technology in the provision of services.

\section{References}

Francis, A.T. (2006) "Library Consortia Model for Country-Wide Access to Electronic Journals and Databases.” Available at http://www.eprints.rdis.org/archive/00004915/02 consortia.pdf.Assessed on 12/09/06

ICOLC (International Coalition of Library Consortia). (2000). "Statement of Current Perspective and Preferred Practices for the Selection and Purchase of Electronic Information.” Available at: http://www.library.yale.edu/consortia/icolcpr.htm

Jalloh, Brimah. (2000). "A plan for the establishment of a library network or consortium for Swaziland: Preliminary Investigations and Formulations.” Library Consortium Management: An International Journal, 2 (8), 165-176.

Jansen, Lloyd. (2003) “The Craft of Local Practice: How Cataloguers are Gaining Efficiency but Losing Control.” OLA Quarterly, 9 (1).

Kammourie Charara, H. (2005) "LALC: A successful challenge. Workshop on Collaborative Management of Electronic Resources.” Cairo. April 18-19. 30p

Kanter, R. M. (1990). “When Giants Learn Cooperative Strategies.” Planning Review, January-February, pp. 15-22

Lee, M. K. and Lee, M. K. (1992). "High Technology Consortia: A Panacea for America’s Technological Competitiveness Problems?” High Technology Law Journal, 6 (2), $335-362$.

Lowe, D and Feighan, D. (2006). "Saving a buck and avoiding the muck: Consortium models in database delivery: the Australian experience.” Assessed on 12/10/2006. Available at: http://www.csu.edu.au/special/online 99/ proceedings 99/ 3021.htm.

Marshall, Breeding. (2002). “The benefits of library partnerships.” Information Today, 19 (19), $42-43$.

Omekwu, C.O. (2003a). "National Agricultural Information Management System in Nigeria: A Conceptual Framework.” Library Review, 52 (9), 444 - 451.

Omekwu, C.O. (2003b). “Current and Critical Issues in Accessing Legal Information.” Library Focus, 22. 1 - 7.

Riemer, John J. (2006) “Web 2.0: Where will it take libraries?” OCLC no. 2 Available at http://www.oclc.org/nextspace/002/5.htm 
Washington Research Library Consortium (2004). "WRLC Program Goals: Shared digital library (Library Information Technology Services). Available at http://www.wrlc.org 